\title{
KAJIAN ANALITIK KINERJA GESER BALOK BETON BERTULANG MENGGUNAKAN RESPONSE-2000
}

\author{
Mayang Indriana Embunsari ${ }^{1)}$, Halwan Alfisa Saifullah ${ }^{2)}$, Achmad Basuki ${ }^{3)}$ \\ 1), 2), 3) Fakultas Teknik, Program Studi Teknik Sipil, Universitas Sebelas Maret \\ J1. Ir. Sutami No. 36A, Kentingan, Surakarta 57126; Telp. (0271) 647069, Fax 634524 \\ Email: halwan@,ft.uns.ac.id
}

\begin{abstract}
Reinforced concrete is a building material which use is increasing in the construction sector. Shear failure in reinforced concrete is avoided because of its brittle nature and could occurs suddenly. Thus, it is necessary to have a good understanding of the factors that affect the shear performance. This study aims to identify the shear performance of reinforced concrete beams with the Response-2000 program based on Modified Compression Field Theory. At the initial step, verification was carried out on the experimental results based on the existing literature. Furthermore, the study was developed with a parametric study of the variation of the compressive strength of concrete, the ratio of flexural and shear reinforcement, the ratio of shear span to effective depth, coarse aggregate size, beam dimensions, and time dependence. The modeling results have a load-deflection curve trend that is close to the experiment. The difference in the percentage of the peak load is 9,21\% and the ultimate deflection is 46,06\%, where Response2000 is underestimated to the experimental deflection value. The results of parametric studies indicate that the increase in the compressive strength of concrete, the ratio of flexural and shear reinforcement, and the size of the coarse aggregate will increase the shear capacity of reinforced concrete beams. On the other hand, an increase in the ratio of shear span to effective height and beam dimensions (size effect) indicates a decrease in shear capacity. This difference in shear capacity is influenced by the contribution of each component that works in the shear transfer mechanism. Parametric study of the effect of time dependence (shrinkage and creep) on the shear strength of reinforced concrete beams are influenced by the contribution of uncracked concrete in the compressive-flexural zone and the bond between aggregates.
\end{abstract}

Keywords: Response-2000, Shear Capacity, Shear Performance, Shear Transfer Mechanism.

\begin{abstract}
Abstrak
Beton bertulang merupakan bahan bangunan yang penggunaannya semakin meningkat dalam konstruksi. Keruntuhan geser pada beton bertulang dihindari karena sifatnya yang getas dan terjadi secara tiba-tiba. Dengan demikian, diperlukan pemahaman yang baik terkait faktor-faktor yang memengaruhi kinerja geser. Penelitian bertujuan mengidentifikasi kinerja geser pada balok beton bertulang dengan program Response-2000 berbasis Modified Compression Field Theory. Pada tahap awal, verifikasi dilakukan terhadap hasil eksperimen berdasarkan literatur yang ada. Selanjutnya, kajian dikembangkan dengan studi parametrik variasi kuat tekan beton, rasio tulangan lentur dan geser, rasio bentang geser terhadap tinggi efektif, ukuran agregat kasar, dimensi balok, dan kebergantungan waktu. Hasil pemodelan memiliki trend kurva beban-lendutan yang mendekati eksperimen. Selisih persentase beban puncak sebesar 9,21\% dan defleksi ultimate sebesar 46,06\%, dimana Response-2000 underestimate terhadap nilai defleksi eksperimen. Hasil studi parametrik menunjukkan bahwa peningkatan kuat tekan beton, rasio tulangan lentur dan geser, serta ukuran agregat kasar akan meningkatkan kapasitas geser balok beton bertulang. Sebaliknya, peningkatan rasio bentang geser terhadap tinggi efektif dan dimensi balok (size effect), menunjukkan penurunan kapasitas geser. Perbedaan kapasitas geser ini dipengaruhi oleh kontribusi dari masing-masing komponen yang bekerja dalam mekanisme transfer geser. Studi parametrik pengaruh kebergantungan waktu (susut dan rangkak) terhadap kuat geser balok beton bertulang dipengaruhi kontribusi beton belum retak di zona tekan-lentur dan ikatan antar agregat.
\end{abstract}

Kata Kunci : Kapasitas Geser, Kinerja Geser, Mekanisme Transfer Geser, Response-2000.

\section{PENDAHULUAN}

Beton bertulang menjadi material yang banyak dipilih dalam kebutuhan infrastruktur karena sifatnya yang kuat terhadap tekan dan tarik, pengerjaan yang mudah, serta tahan terhadap lingkungan. Beton bertulang tersusun dari material yang heterogen, sehingga memungkinkan terjadinya suatu keruntuhan. Keruntuhan geser ditandai dengan munculnya retakan diagonal yang merambat dari daerah sekitar tumpuan menuju ke titik pembebanan. Hal ini dapat dicegah dengan meningkatkan kapasitas geser hingga melebihi kapasitas lenturnya. Modifikasi modus kegagalan geser tidak selalu mudah dilakukan, terutama elemen struktur yang memiliki perilaku geser lebih dominan, seperti transfer beam, pile cap, dan pelat tebal pada terowongan. Oleh karena itu, diperlukan pemahaman terkait faktor-faktor yang memengaruhi kinerja geser pada beton bertulang. Penelitian ini mengembangkan kajian analitik dalam memprediksi kinerja geser balok beton bertulang berdasarkan Modified Compression Field Theory yang diaplikasikan dalam Response-2000. 


\section{METODE}

Metode yang digunakan dalam penelitian adalah pendekatan layered section dengan program Response-2000 versi 1.0.5. Pada analisis pertama, memverifikasi hasil pengujian eksperimen balok beton bertulang dengan modus kegagalan geser. Dilanjutkan analisis kedua, yaitu studi parametrik perilaku geser pada balok yang telah tervalidasi. Variabel bebas yang digunakan adalah kuat tekan beton, rasio tulangan lentur dan geser, rasio bentang geser terhadap tinggi efektif, ukuran agregat kasar, dimensi balok (size effect), serta kebergantungan waktu yang meliputi durasi pembebanan dan intensitas beban. Variabel terikat berupa material properties tertentu dan konfigurasi penampang (Saifullah, 2017). Data yang diperoleh dari penelitian ini berupa hubungan beban-lendutan, beban maksimum, lendutan maksimum, tegangan geser ultimate, regangan beton dan baja tulangan, dan kedalaman sumbu netral balok.

\section{Model Balok}

Model balok yang digunakan adalah beton bertulang tanpa sengkang yang berdimensi $2300 \times 200 \times 320 \mathrm{~mm}^{3}$ dengan rasio bentang geser terhadap tinggi efektif sebesar 3,0. Penelitian menggunakan tulangan baja dengan kekuatan deformasi yang tinggi $\left(f_{y}=1062 \mathrm{MPa}\right)$ dengan rasio tulangan tarik $0,8 \%$ untuk memicu kegagalan geser sebelum melelehnya tulangan tarik. Data input pemodelan balok disesuaikan dengan literatur pengujian eksperimen, yaitu Shear Creep Failures of Reinforced Concrete Slender Beams without Shear Reinforcement (Saifullah, 2017).

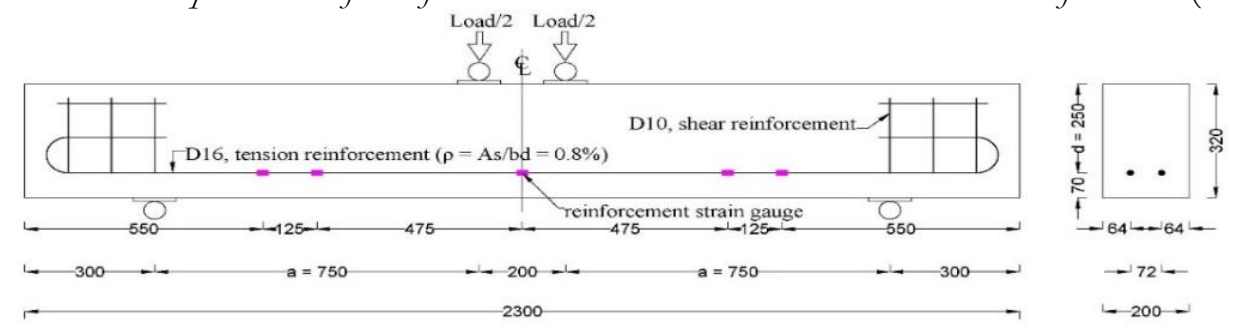

Gambar 1. Model balok beton bertulang tanpa sengkang dengan rasio a/d 3,0 (Saifullah, 2017)

\section{Faktor-Faktor yang Memengaruhi Kuat Geser}

Balok beton bertulang tanpa tulangan geser dapat runtuh apabila terjadi retakan miring. Beberapa faktor yang dapat memengaruhi kuat geser suatu balok beton bertulang adalah sebagai berikut.

1. Rasio bentang geser terhadap tinggi efektif balok

Untuk balok sangat pendek $(0 \leq \mathrm{a} / \mathrm{d} \leq 1)$, perilaku balok setelah terjadi retak miring didominasi oleh aksi pelengkung. Pada balok pendek $(1<\mathrm{a} / \mathrm{d} \leq 2,5)$, keruntuhan yang akan terjadi adalah keruntuhan geser-tarik atau keruntuhan geser-tekan. Pada balok langsing $(2,5<\mathrm{a} / \mathrm{d} \leq 6,5)$, retak yang pertama kali terbentuk adalah retak lentur vertikal, dan dilanjutkan dengan retak lentur-geser miring. Balok panjang $(a / d>6,5)$ akan gagal secara lentur sebelum terbentuknya retakan miring.

2. Kekuatan tekan beton

Balok beton bertulang dapat mengalami keruntuhan tekan-geser, dimana kuat tekan beton dapat mempengaruhi kuat geser balok dengan bergantung pada jenis keruntuhannya.

3. Rasio penulangan longitudinal

Jika rasio tulangan menurun, maka regangan tarik pada tulangan akan bertambah, sehingga menyebabkan lebar retakan lentur semakin besar. Hal ini dapat mengurangi kontribusi mekanisme ikatan antar agregat, beton belum retak di zona tekan-lentur, dan aksi pasak pada tulangan longitudinal terhadap perlawanan geser.

4. Rasio penulangan geser

Dalam meningkatkan kuat geser beton, diperlukan kontribusi dari tulangan geser. Tulangan geser memiliki empat fungsi utama, yaitu menahan gaya geser eksternal, membatasi perkembangan retak diagonal, memegang tulangan longitudinal utama, dan menyediakan pengekangan beton di daerah tekan (sengkang tertutup).

5. Ukuran balok

Peningkatan ketinggian balok dengan sedikit atau tanpa tulangan geser dapat mengakibatkan penurunan geser pada keruntuhan. Fenomena ini dikenal sebagai size effect yang menghasilkan kuat geser yang lebih rendah.

6. Agregat kasar

Ukuran dan kuat agregat berperan penting pada mekanisme ikatan antar agregat. Peningkatan ukuran agregat dapat meningkatkan kekasaran pada permukaan retak dan tegangan geser yang dapat ditransfer lebih tinggi.

\section{Mekanisme Transfer Geser}

Mekanisme transfer geser yang terjadi setelah retak miring pada balok beton bertulang adalah sebagai berikut.

1. Beton yang belum retak di zona tekan-lentur 
Pada balok yang mengalami momen lentur positif, serat penampang atas terjadi tegangan tekan dan serat bawah mengalami tarik. Daerah tekan yang disebabkan oleh lentur mampu menahan geser selama beton belum retak.

2. Ikatan antar agregat

Pada retak miring balok beton bertulang, kontak antara agregat dengan matriks semen akan memberikan perlawanan terhadap slip yang dapat menimbulkan tegangan geser. Walvaren (1980) menjelaskan bahwa agregat yang terikat akan menurun sejalan dengan pertambahan lebar retakan dan kecilnya ukuran agregat.

3. Aksi pasak pada tulangan longitudinal

Aksi pasak merupakan perlawanan tulangan longitudinal terhadap gaya transversal. Saat tegangan transversal bekerja pada tulangan longitudinal, tulangan akan mentransfer tegangan geser melalui aksi lentur dan geser.

4. Sisa kekuatan tarik beton

Setelah terjadi retakan, beton masih mampu menahan tegangan tarik. Tegangan residu muncul pada daerah balok yang sedang mengalami fraktur. Namun, tahanan beton terhadap tarik paska retak nilainya berkurang seiring dengan pertambahan lebar retakan.

5. Aksi pelengkung

Aksi ini dominan untuk balok dengan rasio bentang geser terhadap tinggi efektif yang kecil. Sesaat setelah retak miring, beban dipikul oleh rangkaian reaksi gaya tekan yang membentuk strut diagonal yang menghubungkan antara titik beban dan tumpuan dengan membawa seluruh kontribusi beton dalam menahan geser, serta gaya tarik di sepanjang tulangan longitudinal.

6. Perlawanan tulangan geser

Pemasangan tulangan geser pada beton bertulang dapat menambah gaya perlawanan, yaitu kontribusi dari tulangan geser. Setelah retak miring, sengkang mulai bekerja dengan memberikan ketahanan geser. Saat tulangan sengkang meleleh, luasan tulangan mengalami penurunan yang menyebabkan menurunnya kontribusi sengkang dalam menahan geser.

\section{Response-2000}

Response-2000 merupakan program analisis yang mampu menghitung kekuatan dan daktilitas penampang beton bertulang yang mengalami geser, momen, dan beban aksial. Ketiga beban tersebut secara bersamaan dipakai untuk menentukan respon beban-deformasi penuh beton bertulang berdasarkan Modified Compression Field Theory.

\section{HASIL DAN PEMBAHASAN}

\section{Verifikasi Hasil Eksperimen}

Berdasarkan Gambar 2, dinyatakan bahwa kurva beban-lendutan hasil Response-2000 memiliki trend kurva mendekati hasil eksperimen. Kedua kurva menunjukkan kekakuan awal yang linear dan berhimpit, sehingga terbukti kedua kurva memiliki kesesuaian. Perbedaan terlihat pada tahap transitional non-linear, dimana pemodelan Response-2000 memiliki kekakuan yang lebih tinggi dari hasil eksperimen. Hasil analitik menunjukkan bahwa selisih persentase beban ultimate pemodelan Response-2000 dengan eksperimen hanya sebesar 9,21\%. Sedangkan, selisih persentase defleksi ultimate memiliki perbedaan yang cukup besar, yaitu sebesar 46,06\%. Hal ini mengindikasikan bahwa Response-2000 underestimate terhadap nilai defleksi hasil eksperimen. Jika dilihat dari hasil simulasi kapasitas ultimate, Response-2000 memiliki keandalan dalam membantu proses desain struktur balok beton bertulang.

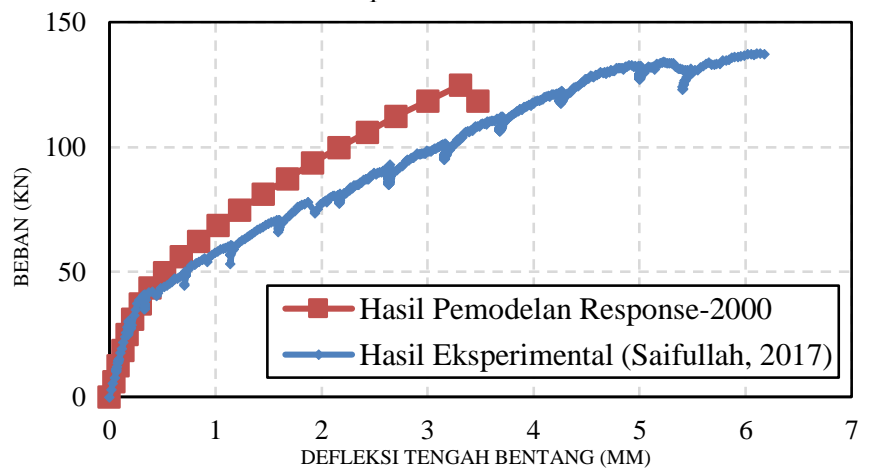

Gambar 2. Perbandingan kurva beban-lendutan pemodelan Response-2000 dengan eksperimen

\section{Studi Parametrik Variasi Kuat Tekan Beton}

Pada Gambar 3(a) menunjukkan bahwa kuat geser balok dengan kuat tekan sebesar $25 \mathrm{MPa}$ sampai $35 \mathrm{MPa}$, terlihat kenaikan beban dan defleksi ultimate yang cukup signifikan. Sedangkan balok dengan kuat tekan sebesar $35 \mathrm{MPa}$ 
sampai $45 \mathrm{MPa}$, hanya terjadi sedikit peningkatan beban dan defleksi ultimate. Peningkatan kuat tekan beton dapat meningkatkan kuat geser balok beton bertulang. Hal ini terjadi karena adanya peningkatan kontribusi beton yang belum retak di zona tekan-lentur dalam menyumbang kuat geser secara keseluruhan. Gambar 3(b) menyajikan perubahan tegangan geser ultimate balok terhadap variasi kuat tekan beton. Terlihat bahwa laju peningkatan kuat geser balok mengalami penurunan seiring dengan peningkatan kuat tekan beton.

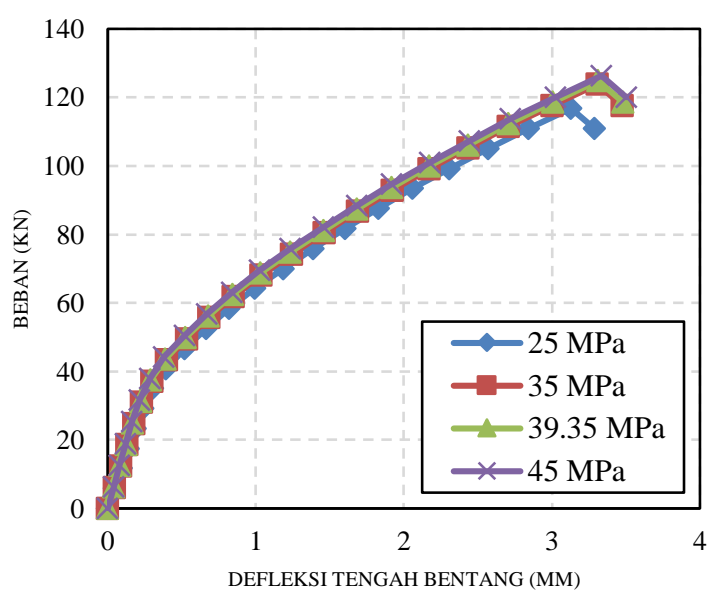

(a)

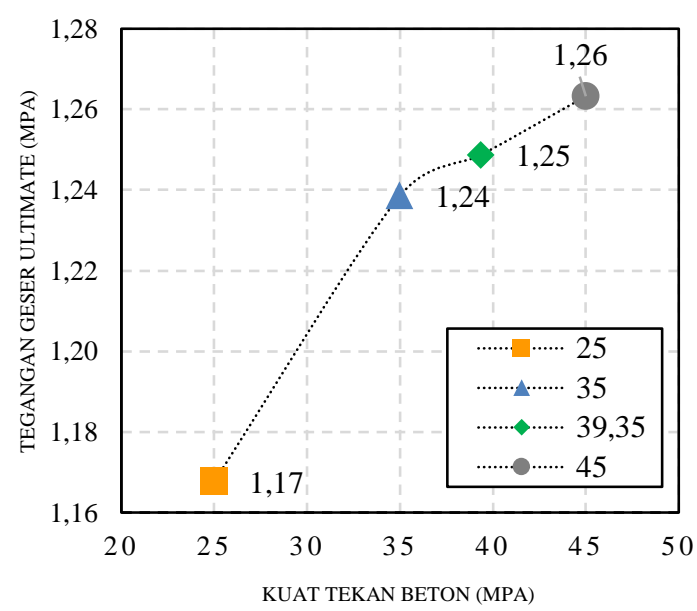

(b)

Gambar 3. Variasi kuat tekan beton (a) Kurva beban-lendutan (b) Perubahan tegangan geser

\section{Studi Parametrik Variasi Rasio Tulangan Lentur}

Pada Gambar 4(a) terlihat semakin besarnya rasio tulangan lentur, maka kekakuan balok menjadi meningkat dan daktilitas balok menjadi berkurang. Dinyatakan bahwa dengan bertambahnya rasio tulangan lentur, maka beban puncak akan meningkat dan defleksi ultimate menurun.

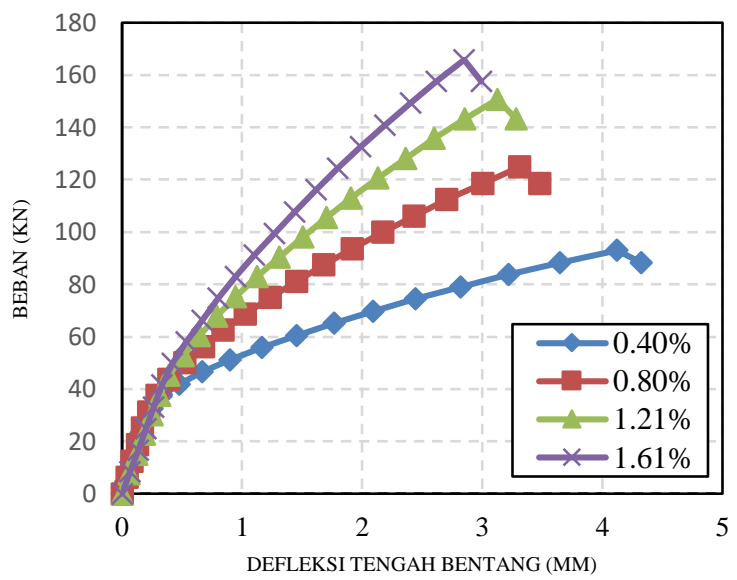

(a)

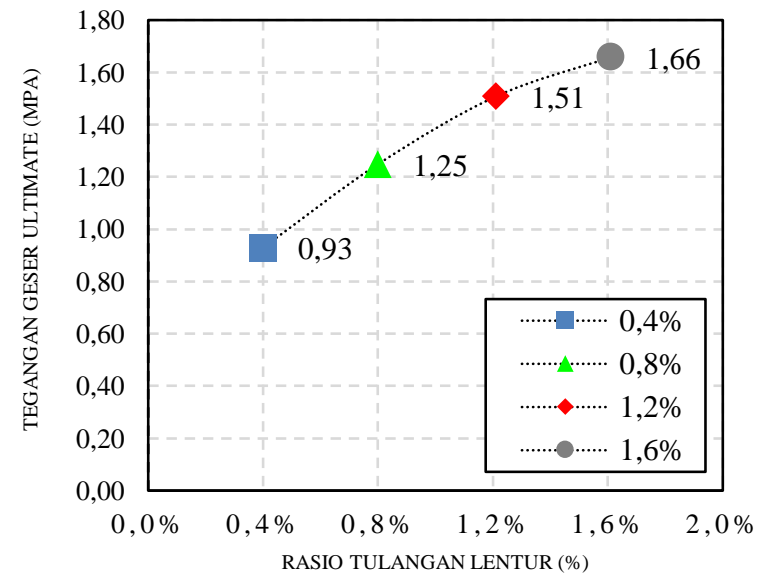

(b)

Gambar 4. Variasi rasio tulangan lentur (a) Kurva beban-lendutan (b) Perubahan tegangan geser

Gambar 4(b) menunjukkan semakin tinggi rasio tulangan lentur, maka terjadi peningkatan tegangan geser ultimate. Penambahan rasio tulangan lentur dapat mengurangi regangan pada tulangan dan lebar retak lentur, dimana menghasilkan kontribusi yang lebih tinggi dari ikatan agregat dan aksi dowel. Selain itu, beberapa peneliti menyatakan peningkatan tulangan lentur menyebabkan peningkatan kedalaman sumbu netral. Hal tersebut akan meningkatkan kontribusi dari beton yang belum retak di zona tekan-lentur dalam menahan gaya geser.

\section{Studi Parametrik Variasi Rasio Tulangan Geser}

Pada Gambar 5(a) menunjukkan bahwa seiring bertambahnya rasio tulangan geser, terjadi peningkatan beban dan defleksi ultimate. Gambar 5(b) menunjukkan semakin tinggi rasio tulangan geser, maka laju peningkatan tegangan geser ultimate semakin mengecil. Penambahan sengkang yang berlebihan atau terlalu rapat menjadi tidak signifikan 
lagi dalam meningkatkan kapasitas geser balok. Ketika retak miring melintasi tulangan geser, maka sengkang memberikan kontribusi terhadap kapasitas struktur dengan meningkatkan atau mempertahankan geser yang ditransfer oleh geser antar permukaan, aksi pasak, dan aksi pelengkung.

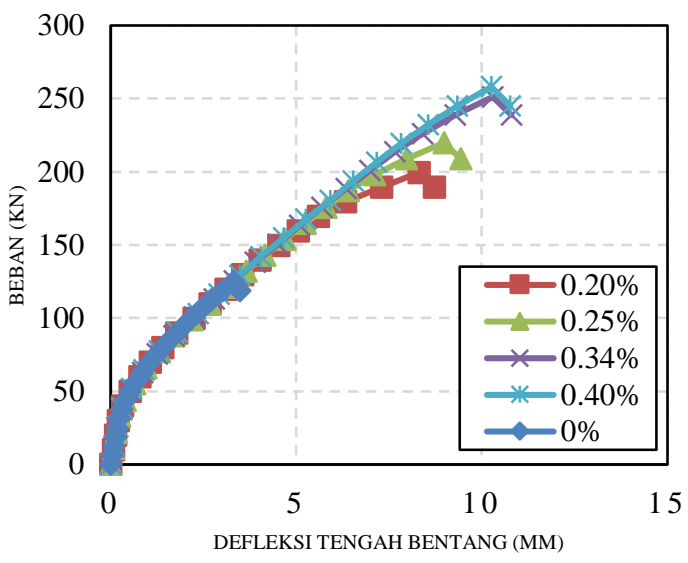

(a)

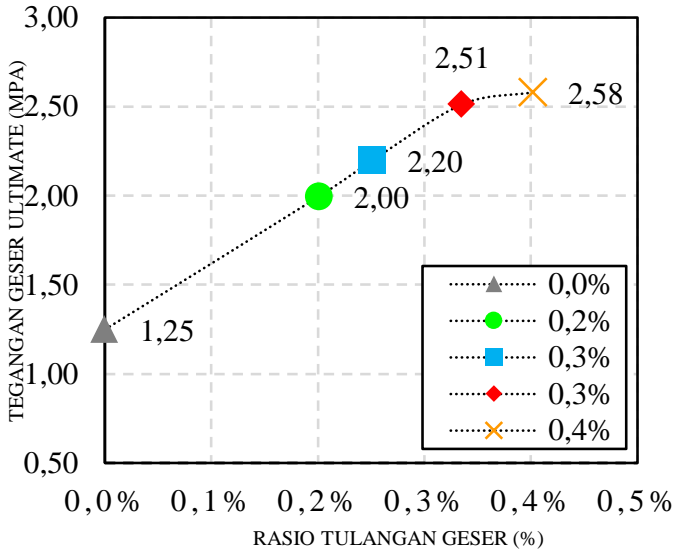

(b)

Gambar 5. Variasi rasio tulangan geser (a) Kurva beban-lendutan (b) Perubahan tegangan geser

\section{Studi Parametrik Variasi Rasio Bentang Geser Terhadap Tinggi Efektif (a/d)}

Pada Gambar 6(a) ditunjukkan semakin besar rasio a/d suatu balok, maka terjadi penurunan beban ultimate dan sifat kekakuan balok semakin menurun. Pada Gambar 6(b) menunjukkan bahwa semakin besar rasio bentang geser terhadap tinggi efektif, maka balok mengalami penurunan kapasitas geser. Pada rasio a/d yang kecil, maka aksi pelengkung akan menjadi dominan dan meningkatkan kapasitas geser balok. Sedangkan, untuk rasio a/d yang besar, aksi balok akan menjadi dominan dan modus keruntuhan mengarah pada keruntuhan lentur.

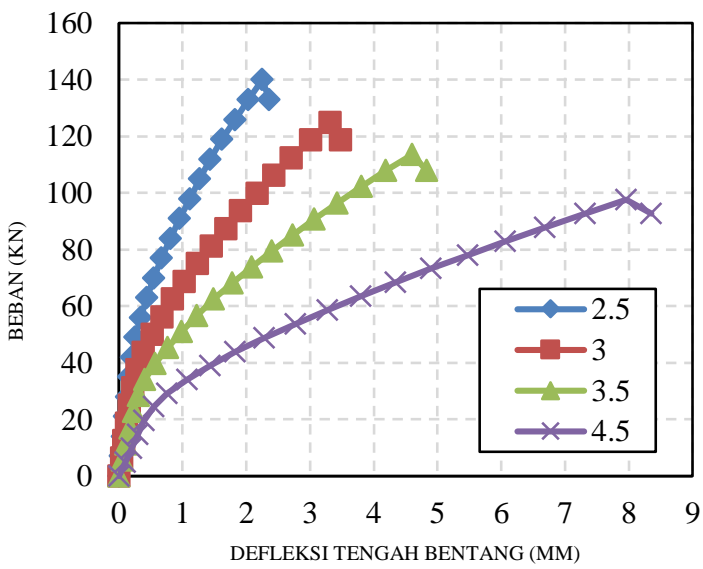

(a)



(b)

Gambar 6. Variasi rasio a/d (a) Kurva beban-lendutan (b) Perubahan tegangan geser

\section{Studi Parametrik Variasi Ukuran Agregat Kasar}

Gambar 7 berikut menampilkan hasil simulasi kuat geser berupa kurva beban-lendutan dan perubahan tegangan geser terhadap variasi ukuran agregat kasar pada balok beton bertulang. 


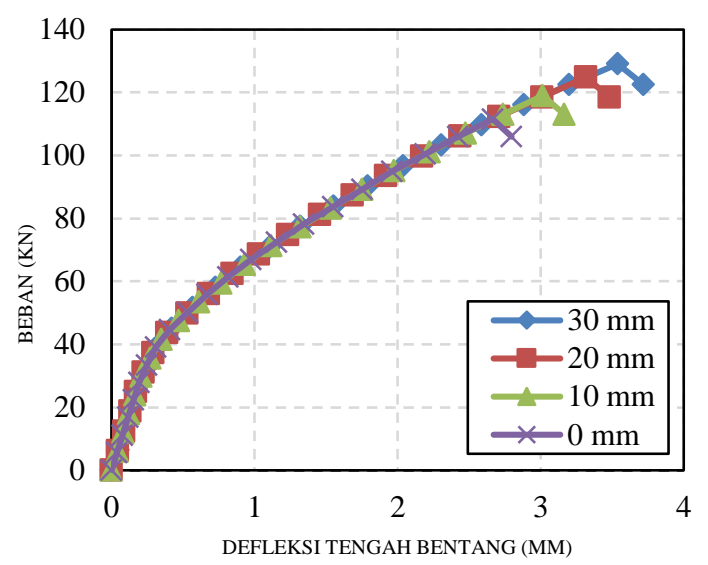

(a)



(b)

Gambar 7. Variasi ukuran agregat kasar (a) Kurva beban-lendutan (b) Perubahan tegangan geser

Pada Gambar 7(a) ditunjukkan setiap kenaikan ukuran agregat kasar, memiliki trend kurva yang bersesuaian. Balok mengalami peningkatan beban dan defleksi ultimate yang cukup konsisten. Selain itu, terlihat bahwa meskipun ukuran agregat kasar ditingkatkan, setiap balok memiliki sifat kekakuan yang cenderung sama. Perbedaan terlihat jelas pada tingkat pembebanan saat terjadi keruntuhan. Gambar 7(b) menunjukkan semakin besar ukuran agregat kasar, dapat meningkatkan kapasitas geser balok. Hal ini karena agregat dengan ukuran yang lebih besar mampu meningkatkan kontribusi ikatan antar agregat melalui permukaan retak yang lebih kasar.

\section{Studi Parametrik Dimensi Balok (Size Effect)}

Pada Gambar 8 disajikan kurva beban-lendutan dan perubahan tegangan geser dengan variasi tinggi efektif balok.



(a)

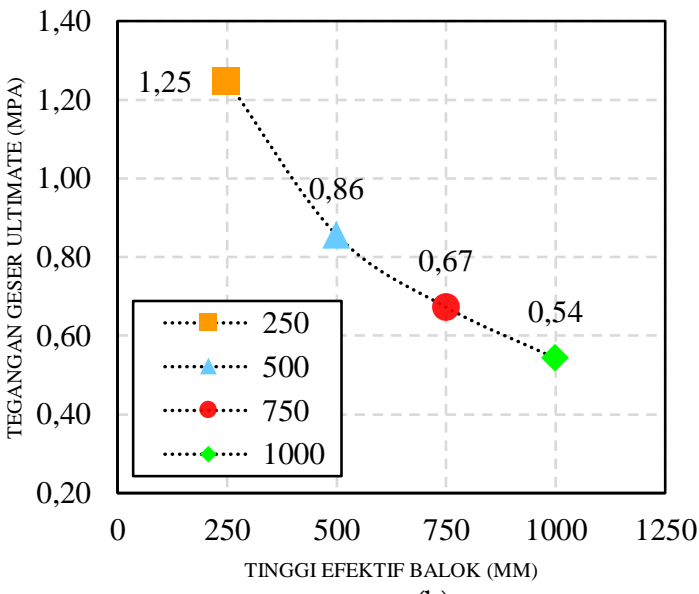

(b)

Gambar 8. Variasi tinggi efektif (a) Kurva beban-lendutan (b) Perubahan tegangan geser

Pada Gambar 8(a) terlihat trend kurva kekakuan awal yang berhimpit. Setiap kenaikan tinggi efektif diikuti dengan meningkatnya beban dan defleksi ultimate. Gambar 8(b) menunjukkan semakin meningkatnya tinggi efektif, maka terjadi penurunan kapasitas geser. Balok dengan ukuran yang lebih besar akan menghasilkan retakan yang lebar di bawah gaya geser, dimana mengurangi kontribusi ikatan antar agregat, sehingga tegangan geser juga akan berkurang.

\section{Studi Parametrik Kebergantungan Waktu}

Rangkak dan susut dapat memengaruhi perilaku beton saat diberikan pembebanan konstan dalam jangka waktu yang lama. Perubahan deformasi pada beton akan bertambah perlahan-lahan seiring dengan berjalannya waktu.

\section{a) Variasi Durasi Pembebanan}

Pada Gambar 9(a), setiap balok menunjukkan defleksi sebelum pembebanan tidak terjadi dari nol. Hal ini karena pengaruh early shrinkage, dimana susut terjadi dalam hitungan jam setelah pengecoran. Seiring meningkatnya durasi pembebanan, pertambahan defleksi awal semakin melambat. Pada Gambar 9(b) dan 9(c), ditampilkan peningkatan 
regangan tekan pada serat teratas beton lebih signifikan dibandingkan regangan tulangan. Pada Gambar 9(d) menunjukkan laju peningkatan tinggi garis netral yang semakin mengecil seiring bertambahnya durasi pembebanan. Perubahan regangan tekan beton, regangan tulangan tarik, dan kedalaman garis netral sangat terkait dengan kinerja geser balok di bawah beban berkelanjutan.

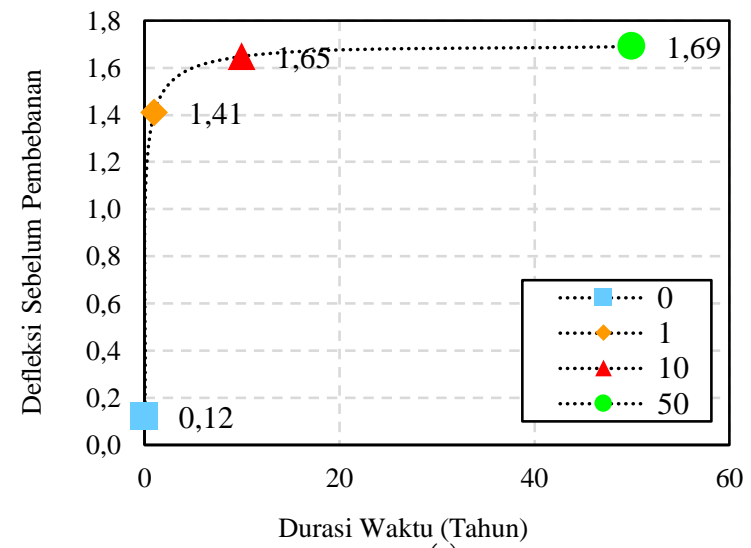

(a)

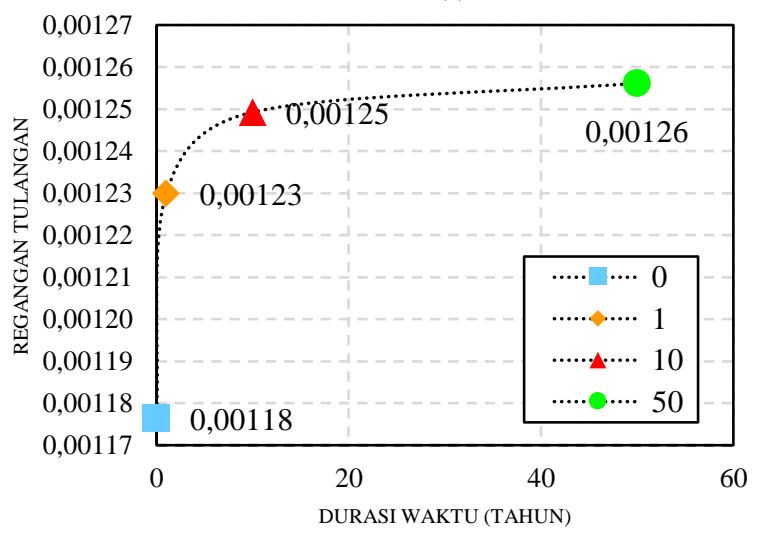

(c)

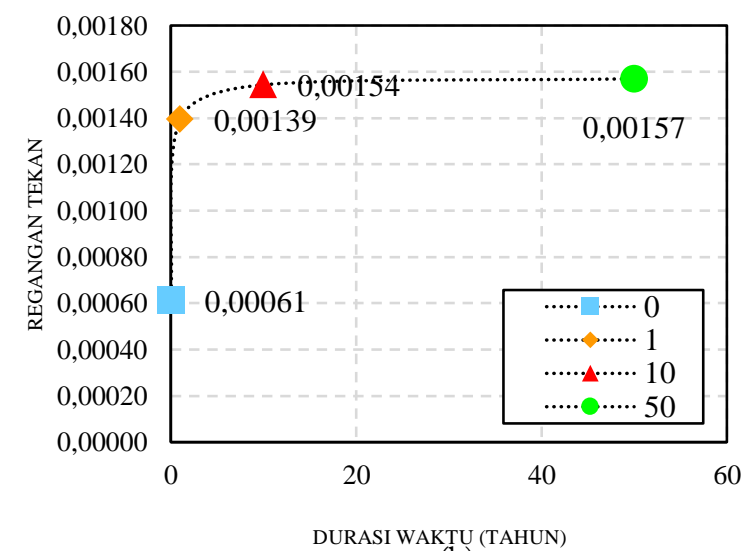

(b)

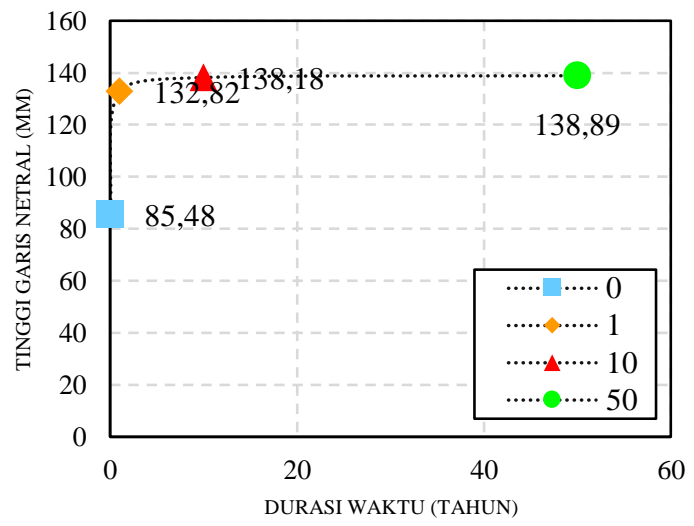

(d)

Gambar 9. Perubahan dengan variasi durasi pembebanan (a) Defleksi awal (b) Regangan tekan (c) Regangan tulangan tarik (d) Tinggi garis netral balok

\section{b) Variasi Intensitas Beban}

Gambar 10(a) menunjukkan defleksi sebelum pembebanan tidak dimulai dari nol karena pengaruh early shrinkage dan terjadi peningkatan yang signifikan. Gambar 10(b) dan 10(c) ditunjukkan seiring pertambahan intensitas beban, terjadi peningkatan regangan tekan dan regangan tulangan yang cukup signifikan. Dari tinjauan kedua regangan, menunjukkan regangan tekan beton mengalami peningkatn yang lebih signifikan dibandingkan regangan tulangan. Kajian ini berkaitan dengan rangkak, dimana setelah beban konstan diberikan, terjadi rangkak yang besar. Lalu seiring berjalannya waktu, pertambahan nilai rangkak semakin melambat. Pada Gambar 10(d) terlihat peningkatan tinggi sumbu netral yang semakin besar seiring bertambahnya intensitas beban. Pada kajian ini, meningkatnya kedalaman garis netral yang diikuti dengan peningkatan kontribusi beton yang belum retak di zona tekan, dapat meningkatkan kapasitas geser. Namun, di sisi lain meningkatnya regangan tulangan mengakibatkan lebar retakan yang juga ikut meningkat, sehingga mengurangi kontribusi ikatan antar agregat yang dapat mengurangi kapasitas geser. Kedua fenomena ini saling mengkompensasi satu sama lain. 


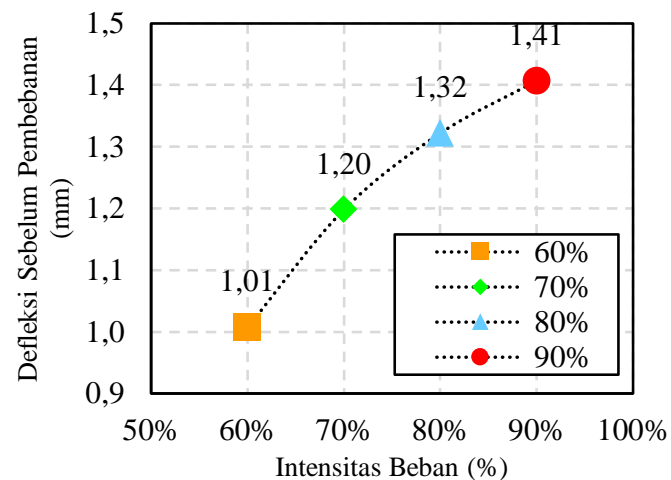

(a)

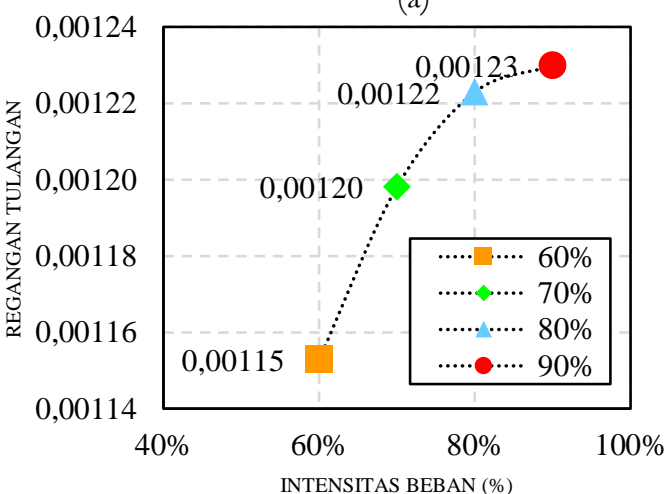

(c)

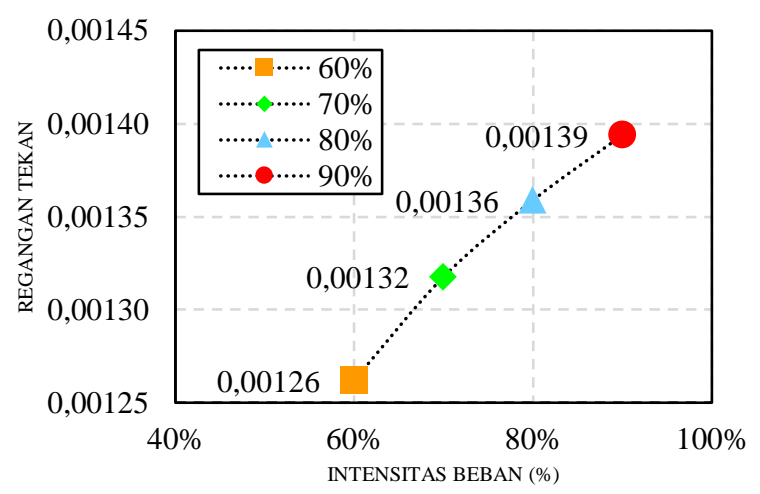

(b)

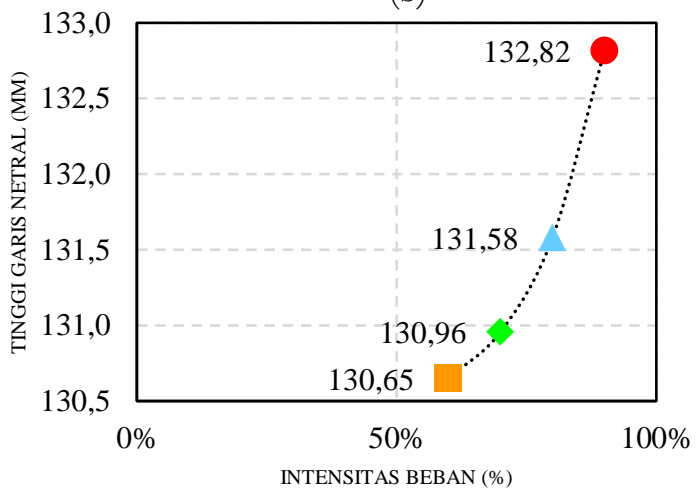

(d)

Gambar 10. Perubahan dengan variasi intensitas beban (a) Defleksi awal (b) Regangan tekan (c) Regangan tulan-

\section{SIMPULAN} gan tarik (d) Tinggi garis netral balok

Berdasarkan proses penelitian yang telah dilakukan, dapat diambil beberapa kesimpulan sebagai berikut.

1. Verifikasi menunjukkan kurva beban-lendutan hasil analitik Response-2000 memiliki trend kurva yang mendekati hasil eksperimen dengan selisih persentase peak. load sebesar 9,21\% dan defleksi ultimate sebesar 46,06\%, dimana Response-2000 underestimate terhadap nilai defleksi pengujian eksperimen balok beton bertulang.

2. Semakin tinggi kuat tekan beton, maka kuat geser balok beton bertulang cenderung meningkat. Hal ini disebabkan oleh peningkatan kontribusi daerah tekan-lentur dalam menahan gaya geser yang bekerja. Akan tetapi, laju peningkatan kuat geser menurun seiring dengan peningkatan kuat tekan material beton.

3. Semakin tinggi rasio tulangan lentur, maka kuat geser balok cenderung semakin meningkat. Penambahan rasio tulangan lentur akan menghasilkan kontribusi lebih tinggi dari ikatan agregat dan aksi dowel. Selain itu, peningkatan tulangan lentur dapat menyebabkan peningkatan kedalaman sumbu netral akibat meningkatnya kontribusi beton belum retak di zona tekan-lentur.

4. Semakin tinggi rasio tulangan geser, maka kapasitas geser balok semakin meningkat dengan laju peningkatan yang menurun. Penambahan tulangan geser yang berlebihan atau terlalu rapat menjadi tidak signifikan lagi dalam meningkatkan kapasitas geser. Tulangan geser berkontribusi dalam membatasi pelebaran retak miring balok dan memperlambat penurunan transfer geser antar permukaan.

5. Semakin besar rasio bentang geser terhadap tinggi efektif (a/d), maka terjadi penurunan kapasitas geser balok. Pada rasio a/d yang kecil, aksi pelengkung menjadi dominan dan akan meningkatkan kapasitas geser. Sedangkan rasio a/d yang besar, aksi balok menjadi dominan dan modus keruntuhan mengarah pada keruntuhan lentur.

6. Semakin besar ukuran agregat kasar, maka meningkatkan kapasitas geser balok. Hal ini karena agregat dengan ukuran yang lebih besar mampu meningkatkan ikatan antar agregat melalui permukaan retak yang lebih kasar.

7. Semakin bertambahnya tinggi efektif balok, maka terjadi penurunan kapasitas geser. Balok dengan ukuran yang lebih besar menghasilkan retakan yang lebar, dimana akan mengurangi kontribusi ikatan antar agregat, sehingga tegangan geser juga akan berkurang. 
8. Seiring bertambahnya durasi pembebanan, maka laju peningkatan defleksi awal akibat susut semakin menurun. Sedangkan dengan bertambahnya intensitas beban, maka peningkatan defleksi awal cukup signifikan. Seiring bertambahnya durasi pembebanan dan intensitas beban, menghasilkan peningkatan regangan tekan beton yang lebih signifikan dibandingkan regangan tulangan yang dipengaruhi oleh rangkak. Seiring bertambahnya durasi pembebanan, maka laju peningkatan tinggi garis netral semakin mengecil. Sedangkan seiring bertambahnya intensitas beban, maka laju peningkatan tinggi garis netral semakin besar. Peningkatan kedalaman garis netral diikuti dengan meningkatnya kontribusi beton yang belum retak di zona tekan-lentur yang dapat meningkatkan kapasitas geser. Akan tetapi, meningkatnya regangan tulangan mengakibatkan lebar retakan yang meningkat, sehingga akan mengurangi ikatan antar agregat yang dapat menurunkan kapasitas geser balok.

\section{UCAPAN TERIMA KASIH}

Penelitian ini didanai oleh RKAT PTNBH Universitas Sebelas Maret Tahun Anggaran 2021 melalui skema penelitian hibah grup riset (penelitian hgr-uns) dengan Nomor Kontrak: 260/UN27.22/HK.07.00/2021

\section{REFERENSI}

Bentz, E., 2000, “Sectional Analysis of Reinforced Concrete Members", Ph.D. Thesis, Departement of Civil Engineering, University of Toronto, Kanada.

Bentz, E., and M. P. Collins, 2001, "Response-2000 User Manual Version 1.1”, University of Toronto, Kanada.

Gilbert, R. I., 2012, "Creep and Shrinkage Induced Deflections in RC Beams and Slabs", Paper, School of Civil and Environmental Engineering, University of New South Wales, Australia.

Saifullah, H. A., K. Nakarai, V. Piseth, N. Chijiwa, and K. Maekawa, 2017, "Shear Creep Failures of Reinforced Concrete Slender Beams without Shear Reinforcement”, ACI Structural Journal, Vol. 114 No. 6, November-December.

Walraven, J. C., 1980, “Aggregate Interlock: A Theoretical and Experimental Analysis", Doctoral Thesis, Department of Civil Engineering, Delft University of Technology, Netherlands.

Wight, J. K., dan J. G. MacGregor, 2012, “Reinforced Concrete Mechanics and Design”, Six Ed., Pearson Education Inc.New Jersey. 